\title{
UPAYA KEPALA SEKOLAH DALAM MENINGKATKAN KREATIFITAS GURU DI MI MUHAMMADIYAH 15 BANJARWATI PACIRAN LAMONGAN
}

\author{
M. CHOTIBUDDIN \\ Dosen Sekolah Tinggi Ilmu Tarbiyah Muhammadiyah Paciran
}

Abstract: The aim of this research is to analyze the efforts of Principal in improving the creativity of teachers in MI Muhammadiyah Lamongan 15 Banjarwati Paciran which was held in October 2016 and November 2016. This research uses descriptive research to obtain data from observation, interview and documentation. The research sample are principals and all teachers in 15 Banjarwati Paciran MI Muhammadiyah Lamongan. The Efforts that can be made by the principal in improving the creativity of teachers are 1) giving reward for creative teachers. 2) giving the career path 3) giving training systems.

Keywords: attempt principal, teacher creativity.

Persaingan di era globalisasi saat ini sangat unik dan kompleks. Persaingan tidak hanya mengarah pada satu bidang saja akan tetapi persaingan yang akan dihadapi adalah persaingan yang bersifat universal artinya persaingan yang meliputi semua bidang.

Salah satu persaingan yang sedang menjadi wacana adalah persaingan dalam bidang pendidikan dimana didalamnya melibatkan persaingan kualitas kemampuan sumber daya manusia yang yang harus memiliki keunggulan agar mampu menciptakan pendidikan yang berkualitas dalam menghadapi era globalisasi dan informasi ini. Dengan alasan pemikiran tersebut, kemampuan yang diperlukan adalah kemampuan memiliki kecerdasan dan kreativitas dalam Iptek, memiliki kepribadian dan keterampilan hidup.

Oleh karena itu , guru sebagai salah satu sumber daya manusia yang ada dalam dunia pendidikan sebagai ujung tombak dalam melaksanakan proses kegiatan pendidikan tentunya harus memiliki ideide kreatif dan inovatif dalam tugas dan fungsinya sebagai tenaga pendidik bagi peserta didik dalam proses kegiatan belajar mengajar. Sehingga dengan ide kreatif guru diharapkan dapat tercipta lingkungan belajar yang menyenangkan dan semua kesulitan belajar peserta didik dapat diatasi dengan baik, hal ini dilakukan sebagai upaya dalam rangka menciptakan pendidikan yang berkualitas.

Akan tetapi tidak semua guru dapat secara langsung memiliki kreatifitas dalam pekerjaanya.oleh karena itu, perlu adanya dukungan dan upaya dari pihak tertentu salah satunya adalah kepala sekolah sebagai pemimpin dan penentu arah kebijakan pendidikan di sekolah untuk membantu guru dalam meningkatkatkan kreatifitasnya.

Tujuan Penelitian ini adalah untuk mengetahui upaya - upaya yang dilakukan oleh kepala sekolah dalam meningkatkan kreatifitas guru yang ada di MI Muhammadiyah 15 Banjarwati. Manfaat penelitian ini di harapkan dapat dijadikan sebagai evaluasi untuk kemajuan kinerja kepala sekolah dan guru yang akan datang, dan dapat sebagai referensi untuk penelitian selanjutnya dengan upaya kepala sekolah yang lebih lengkap. 


\section{KAJIAN TEORI \\ Pengertian peran kepala sekolah}

Secara etimologi kepala sekolah adalah guru yang memimpin sekolah (Poerwadarminto, 1976: 482). Berarti secara terminology kepala sekolah dapat diartikan sebagai tenaga fungsional guru yang diberikan tugas tambahan untuk memimpin suatu sekolah di mana diselenggarakan proses belajar mengajar atau tempat di mana terjadi interaksi antara guru yang memberi pelajaran dan murid yang menerima pelajaran.

Kepala Sekolah adalah pimpinan tertinggi di sekolah. Pola kepemimpinananya akan sangat berpengaruh bahkan sangat menentukan kemajuan sekolah. Oleh karena itu dalam pendidikan modern kepemimpinan kepala sekolah merupakan jabatan strategis dalam mencapai tujuan pendidikan.

Soewadji Lazaruth (1994: 20) menjelaskan 3 fungsi kepala sekolah, yaitu sebagai administrator pendidikan, supervisor pendidikan, dan pemimpin pendidikan. Kepala sekolah berfungsi sebagai administrator pendidikan berarti untuk meningkatkan mutu sekolahnya, seorang kepala sekolah dapat memperbaiki dan mengembangkan fasilitas sekolahnya misalnya gedung, perlengkapan atau kepala sekolah adalah melaksanakan kegiatan pemeliharaan dan pengembangan profesi para guru.

3. Kepala Sekolah Sebagai Administrator Khususnya berkenaan dengan pengelolaan keuangan, bahwa untuk tercapainya peningkatan kompetensi guru tidak lepas dari faktor biaya.

4. Kepala Sekolah Sebagai Supervisor Untuk mengetahui sejauh mana guru mampu melaksanakan pembelajaran, secara berkala kepala sekolah perlu melaksanakan kegiatan supervisi, yang dapat dilakukan melalui kegiatan kunjungan kelas untuk mengamati proses pembelajaran secara langsung, terutama dalam pemilihan dan peralatan dan lain-lain yang tercakup dalam bidang administrasi pendidikan. Lalu jika kepala sekolah berfungsi sebagai supervisor pendidikan berarti usaha peningkatan mutu dapat pula dilakukan dengan cara peningkatan mutu guru-guru dan seluruh staf sekolah, misalnya melalui rapat-rapat, observasi kelas, perpustakaan dan lain sebagainya. Dan kepala sekolah berfungsi sebagai pemimpin pendidikan berarti peningkatan mutu akan berjalan dengan baik apabila guru bersifat terbuka, kreatif dan memiliki semangat kerja yang tinggi. Suasana yang demikian ditentukan oleh bentuk dan sifat kepemimpinan yang dilakukan kepala sekolah. Itulah pendapat Soewadji Lazaruth dalam bukunya Kepala Sekolah dan Tanggung Jawabnya, yang kurang lebih sama dengan pendapat E. Mulyasa dalam bukunya Menjadi Kepala Sekolah Profesional, seperti di bawah ini. Menurut E. Mulyasa (2007: 98- 122

), kepala sekolah mempunyai 7 fungsi utama, yaitu:

1. Kepala Sekolah Sebagai Educator (Pendidik)

Kegiatan belajar mengajar merupakan inti dari proses pendidikan dan guru merupakan pelaksana dan pengembang utama kurikulum di sekolah.

2. Kepala Sekolah Sebagai Manajer

Dalam mengelola tenaga kependidikan, salah satu tugas yang harus dilakukan penggunaan metode, media yang digunakan dan keterlibatan siswa dalam proses pembelajaran.

5. Kepala Sekolah Sebagai Leader (Pemimpin)

Mulyasa menyebutkan kepemimpinan seseorang sangat berkaitan dengan kepribadian, dan kepribadian kepala sekolah sebagai pemimpin akan tercermin sifat-sifat sebagai barikut : (1) jujur; (2) percaya diri; (3) tanggung jawab; (4) berani mengambil resiko dan keputusan; (5) berjiwa besar; (6) emosi yang stabil, dan (7) teladan.

6. Kepala Sekolah Sebagai Inovator Dalam rangka melakukan peran dan fungsinya sebagai innovator, kepala 
sekolah harus memiliki strategi yang tepat untuk menjalin hubungan yang harmonis dengan lingkungan, mencari gagasan baru, mengintegrasikan setiap kegiatan, memberikan teladan kepada seluruh tenaga kependidikan sekolah, dan mengembangkan model model pembelajaran yang inovatif. Kepala sekolah sebagai inovator akan tercermin dari cara cara ia melakukan pekerjaannya secara konstruktif, kreatif, delegatif, integratif, rasional, objektif, pragmatis, keteladanan

7. Kepala Sekolah Sebagai Motivator Sebagai motivator, kepala sekolah harus memiliki strategi yang tepat untuk memberikan motivasi tenaga kependidikan dalam melaksanakan tugas dan fungsinya. Motivasi ini dapat ditumbuhkan melalui pengaturan lingkungan fisik, pengaturan suasana kerja, disiplin, dorongan, penghargaan secara efektif, dan penyediaan berbagai sumber belajar melalui pengembangan Pusat Sumber Belajar (PSB).

Menurut Purwanto (Purwanto, 2002: 65), bahwa seorang kepala sekolah mempunyai sepuluh macam peranan, yaitu : "Sebagai pelaksana, perencana, seorang ahli, mengawasi hubungan antara anggotaanggota, mewakili kelompok, bertindak sebagai pemberi ganjaran, bertindak sebagai wasit, pemegang tanggung jawab, sebagai seorang pencipta, dan sebagai seorang ayah."

\section{Pengertian kreatifitas guru}

Kreativitas guru merupakan istilah yang banyak digunakan, baik di lingkungan sekolah maupun luar sekolah. Pada umumnya orang menghubungkan kreativitas dengan produk-produk kreasi. Dengan kata lain produk-produk kreasi itu merupakan hal yang penting untuk menilai kreativitas. Clark Monstakos, seorang psikolog humanistis menyatakan bahwa kreativitas adalah pengalaman mengekspresikan (mengaktualisasikan) identitas individu dalam bentuk terpadu dalam hubungan dengan diri sendiri, dengan alam dan orang lain (Munandar, 2002: 24).

Pada dasarnya pengertian kreatif berhubungan dengan penemuan sesuatu, mengenai hal yang menghasilkan sesuatu yang baru dengan menggunakan sesuatu yang telah ada (Slameto, 1995: 145).

Dari situlah sehingga dapat diartikan bahwa guru yang kreatif adalah guru yang mampu mengaktualisasikan dan mengekspresikan secara optimal segala kemampuan yang ia miliki dalam rangka membina dan mendidik anak didik dengan baik. Seorang guru yang kreatif akan memiliki sikap kepekaan, inisiatif, cara baru dalam mengajar, kepemimpinan serta tanggungjawab yang tinggi dalam pekerjaan dan tugasnya sebagai seorang pendidik.

Sebagaimana telah dikemukakan sebelumnya, bahwa guru bukanlah sekedar orang yang berdiri di depan kelas untuk menyampaikan materi pengetahuan tertentu, akan tetapi adalah anggota masyarakat yang harus ikut aktif dan berjiwa besar serta kreatif dalam mengarahkan perkembangan anak didiknya untuk menjadi anggota masyarakat yang dewasa.

Ada yang mengatakan bahwa mengajar itu adalah seni (art), karena mengajar itu membutuhkan inspirasi, intuisi, dan kreativitas (Soekartini, 1995: 32).

A. A. Mangun-harjana (1986: 27) yang menukil salah satu ilmuwan barat mengata-kan bahwa mengembangkan kreativitas itu menjadi sesuatu yang sangat berpengaruh dalam kemajuan hidup. Orang yang berkreatif atas itu bercirikan lincah, kuat mental dapat berfikir dari segala arah maupun ke segala arah, dan yang terpenting mempunyai keluwesan konseptual, orisinalitas dan menyukai kerumitan. Ciri-ciri tersebut masih harus ditambah lagi dengan sifat mau bekerja keras, mandiri, pantang menyerah, dan lebih tertarik pada konsep besar, punya selera humor dan fantasi serta tidak menolak ide-ide yang ada di depanya. 
Ada teori yang mengatakan "kreativitas merupakan titik pertemuan yang khas antara tiga atribut Psikologis yaitu intelegensi, gaya kognitif, dan kepribadian atau motivasi". Secara bersamaan tiga segi dalam pikiran ini membantu memahami apa yang melatar belakangi individu yang kreatif (Munandar, 2002: 26).

Intelegensi meliputi kemampuan verbal, pemikiran lancar, pengetahuan, perumusan masalah, penyusunan strategi, representasi mental, keterampilan pengambilan keputusan dan keseimbangan serta integrasi intelektual secara umum.

Gaya kognitif atau intelektual dari pribadi kreatif menunjukkan kelonggaran dan keterikatan konvensi, menciptakan aturan sendiri, melakukan hal-hal dengan caranya sendiri dan menyukai masalah yang tidak terlalu berstruktur. Dimensi kepribadian dan motivasi meliputi ciri-ciri seperti kelenturan, dorongan untuk berprestasi dan mendapat pengakuan keuletan dalam menghadapi rintangan dan pengambilan resiko yang moderat.

\section{Upaya meningkatkan kreatifitas guru}

Sebagaimana teori motivasi yang dapat meningkatkan kreatifitas dan kinerja guru seperti teori kebtuhan manusia oleh Mac Cleland yaitu Need for Achievement, need for Power dan need for Affilization. Usaha nyata untuk dapat mencapai kebutuhan tersebut adalah sebagai berikut: (http://sdnegeri2sibuhuan.blogspot.co.id/2 013/06/usaha-meningkatkan-kreativitasguru.html diakses tanggal 12 november 2016).

1. Pemberian reward bagi guru kreatif

2. Pemberian jenjang karier yang sesuai

3. Sistem training

\section{METODE}

Penelitian ini menggunakan jenis penelitian Deskriptif. deskriptif adalah penelitian yang berusaha mendeskripsikan suatu gejala, peristiwa, kejadian yang terjadi pada saat sekarang. Penelitian ini dilaksanakan pada bulan Oktober 2016 sampai dengan bulan November 2016. Penelitian ini telah di laksanakan di MI Muhammadiyah 15 Banjarwati Paciran Lamongan.

Populasi adalah seluruh data yang menjadi perhatian kita dalam suatu ruang lingkup dan waktu yang kita tentukan (Margono, 2010: 118). Populasi dalam penelitian ini adalah kepala sekolah dan seluruh guru yang ada di MI Muhammadiyah 15 Banjarwati.

Sampel adalah sebagian dari jumlah dan karakteristik yang dimiliki oleh populasi tersebut. penentuan pengambilan sampel sebagai berikut: "Apabila subjeknya kurang dari 100 lebih baik diambil semua sehingga penelitiannya merupakan penelitian populasi" (Arikunto, 2006: 141). Pengambilan Sampel secara total yaitu Kepala Sekolah dan Seluruh dewan gur yang ada di MI Muhammadiyah 15 Banjarwati.

Teknik pengumpulan data yang meliputi 1) Observasi yaitu dengan cara mengamati keadaan oyek yang diteliti secara langsung. 2) Wawancara yaitu dengan mengadakan tanya jawab kepada kepala sekolah MI Muhammadiyah 15 Banjarwati mengenai hal-hal yang berkaitan dengan peran Kepala sekolah dalam meningkatkan kreatifitas guru di MI Muhammadiyah 15 Banjarawti Paciran Lamongan.; 3) Dokumentasi yaitu menganalisis literatur maupun terbitanterbitan dari instansi terkait berkenaan dengan upaya kepala sekolah dalam meningkatkan kreatifitas Guru.

Dalam penelitian ini, dilakukan analisis kualitatif model miles dan hubermen dengan langkah-langkah sebagai berikut:

1) Tahap reduksi data

2) Tahap penyajian data

3) Tahap penarikan kesimpulan

\section{Paparan Dan Pembahasan Data Hasil Penelitian}

Dari hasil pengamatan dan wawancara non formal yang dilakukan 
oleh peneliti terhadap dewan guru yang ada di MI Muhammadiyah 15 Banjarwati, maka dapat disimpulkan bahwa kreatifitas guru yang ada di lembaga tersebut masih kurang dari yang diharapkan. Hal ini dapat dibuktikan dengan adanya beberapa temuan sebagai berikut : 1) masih ada beberapa guru yang belum dapat melaksanakan tugasnya dengan baik. 2) masih ada beberapa guru yang masih menggunakan metode konvensional dalam melaksanakan pembelajaran 3) masih ada beberapa guru yang masih belum bisa menggunakan alat peraga dan alat penunjang kegiatan pembelajaran. Selain itu terdapat juga temuan bahwa kepala sekolah dalam mengatasi masalahmasalah tersebut cenderung hanya memberikan nasehat dan teguran melalui kegiatan supervisi guru. Untuk itu perlu adanya tindakan nyata dari kepala sekolah dalam meningkatkan kreatifitas guru disekolah. Adapun upaya yang bisa dilakukan oleh kepala sekolah adalah :

1) pemberian reward bagi guru kreatif

2) Pemberian jenjang karir yang jelas.

3) Sistem training

Kegagalan dan keberhasilan sekolah banyak ditentukan oleh kepala sekolah, karena kepala sekolah merupakan pengendali dan penentu kebijakan dalam pencapaian visi, misi dan tujuan sekolah. Oleh karena itu ada beberapa upaya yang dilakukan oleh kepala sekolah untuk meningkatan kreatifitas guru yaitu : 1) Pemberian reward bagi guru kreatif. 2) Pemberian karir yang jelas.3) pemberian sistem training

\section{Pemberian reward bagi guru kreatif}

Penghargaan atas kreativas seorang guru yang meningkatkan kinerjanya sudah sewajarnya mendapatkan reward . Dengan pemberian reward untuk menghargai kinerja seorang guru maka guru tersebut akan lebih termotivasi untuk lebih berkreasi. Dalam hal ini peneliti menemukan temuan dilapangan bahwa upaya pemberian reward bagi guru kreatif belum terlaksana dengan baik di sekolah tersebut. Selain itu, berdasarkan wawancara yang telah dilakukan oleh peneliti kepada beberapa guru yang ada disekolah tersebut, mereka belum pernah mendapatkan reward atau penghargaan dalam bentuk apapun dari sekolah meskipun mereka bisa digolongkan sebagai guru yang kreatif. (Wawancara dengan Mohammad Qomari S. PdI pada tanggal 13 November 2016). Padahal dengan adanya pemberian reward dari sekolah diharapkan mampu memberikan dorongan lebih kepada guru untuk menjadi lebih kreatif.

\section{Pemberian jenjang karir yang jelas}

Didalam pelaksanaan tugas sebagai Kepala Sekolah Mohammad Umar, M PdI, memberikan kebijakan dalam hal pemberian jenjang karir guru melalui pengajuan program sertifikasi dan program inpassing guru kepada beberapa guru yang telah memenuhi persyaratan tertentu untuk diajukan dalam memperoleh tunjangan profesi guru. Hal ini sangat berdampak kepada guru tersebut karena guru yang mengikuti program tersebut dituntut untuk menemukan inovasi dan ide- ide kreatif dalam kegiatan pembelajaran dan mengedepankan profesionalitas dalam kinerjanya sebagai guru. Berdasarakan hasil wawancara terhadap guru- guru yang telah diajukan program tersebut dapat disimpulkan bahwa guru yang diajukan program tersebut dituntut untuk lebih kreatif, inovatif dan profesional dalam pekerjaanya sebagai guru (Wawancara dengan Tafif abdurrahman, S Pd pada tanggal 13 November 2016). Dan dari hasil pengamatan yang dilakukan oleh peneliti menemukan bahwa guru yang telah diajukan program sertifikasi guru lebih menonjol dalam hal kepekaan, inisiatif, cara baru dalam mengajar, kepemimpinan serta tanggung jawabnya. 


\section{Sistem training ( Staff Upgrading)}

Berdasarkan tugasnya sebagai Kepala Sekolah Mohammad Umar M, PdI memberikan kebijakan kepada guru untuk meningkatkan kreatifitasnya dengan mengikuti penataran- penataran, pelatihan dan diklat bagi guru untuk menambah wawasan dan pengetahuannya tentang apa dan bagaimana menjadi guru yang kreatif dan inovatif (Wawancara dengan Fathur Rozi, S PdI pada tanggal 14 November 2016). Hal ini diharapkan dapat menjadi media bagi guru untuk saling bertukar pikiran satu dengan yang lain sehingga segala keluhan dan permasalahan guru dalam kegiatan pembelajaran dapat diatasi. Berdasarkan wawancara yang dilakukan oleh peneliti terhadap guru yang pernah mengikuti pelatihan, peneliti menemukan bahwa dengan mengikuti pelatihan dapat mempermudah guru untuk melaksankan tugasnya karena didalam pelatihan tersebut guru diberikan pembinaan dan bimbingan untuk menjadi guru yang kreatif dalam memberikan materi pembelajaran dan diberikan solusi- solusi terhadap semua masalah yang sering dihadapi oleh guru disekolah.

\section{KESIMPULAN DAN SARAN}

Upaya yang dilakukan oleh kepala sekolah dalam meningkatkan kreatifitas guru adalah dengan cara :1) pemberian jenjang karir yang jelas kepada guru yang telah memenuhi syarat untuk diajukan mengikuti program sertifikasi guru dan inpassing.2) sistem training, kepala sekolah memberikan kebijakan kepada guru untuk ikut serta dalam pelatihanpelatihan, diklat dan penataran guru yang ada untuk menambah wawasan dan pengetahuan guru.

Adapun upaya yang belum terlaksana adalah adanya pemberian reward dari sekolah bagi guru kreatif.

Sehingga dalam hal ini peneliti menyarankan agar kepala sekolah memberikan kebijakan tetang adanya pemberian reward kepada guru kreatif untuk meningkatkan kualiats guru yang ada di sekolah tersebut. Dengan adanya reward baik itu berupa uang ataupun barang tertentu kepada guru akan menjadi motivasi tersendiri bagi guru untuk meningkatkan kualitas dan kreatifitasnya.

\section{DAFTAR RUJUKAN}

A.A. Mangunharjana. 1986. Mengembangkan Kreativitas. Yogyakarta : Kanisius.

E. Mulyasa. 2007. Menjadi Kepala Sekolah Profesional. Bandung : PT Remaja Rosdakarya.

Munandar. 2002. Kreativitas dan Keterbakatan Strategi Mewujudkan Potensi Kreatif dan Bakat. Jakarta : PT Gramedia Pustaka Utama.

Soekartini. 1995. Meningkatkan Efektivitas Mengajar. Jakarta : Pustaka Jaya

Soewadji Lazaruth. 1994. Kepala Sekolah dan Tanggung Jawabnya. Cetakan ke 6. Yogyakarta: Kanisius

W.J.S. Poerwadarminto. 1976. Kamus Umum Bahasa Indonesia. Jakarta: Balai Pustaka

http://sdnegeri2sibuhuan.blogspot.co.id/20 13/06/usaha-meningkatkankreativitas-guru.html diakses tanggal 12 november 2016 